\title{
Importance of Integrated Water Resources Management in Flood and Flash Flood Management
}

\author{
Nino Tkhilava \\ Department of Environmental Policy and International Relations, Ministry of Environment and Natural Resources Protection, Tbilisi, \\ Georgia
}

Email address:

Nino.tkhilava@moe.gov.ge

To cite this article:

Nino Tkhilava. Importance of Integrated Water Resources Management in Flood and Flash Flood Management. American Journal of Environmental Protection. Special Issue: Applied Ecology: Problems, Innovations. Vol. 4, No. 3-1, 2015, pp. 8-13.

doi: 10.11648/j.ajep.s.2015040301.12

\begin{abstract}
Water resources management setup and practices in Georgia are relied on administrative approaches. Gradual introduction and implementation of the river basin based Integrated Water Resources Management (IWRM) will require corresponding legal and institutional adjustment as well as significant capacity building. The IWRM model for Georgia is intended to address prioritized concerns regarding water resource management, based on extensive consultations with stakeholders from a wide range of agencies and institutions related to water issues. Managing water efficiently, balancing conflicting uses of water resources, eliminating the results of catastrophic floods causing loss of human lives and damages to infrastructure and settlements and ensuring environmental stability of the river basins are critical issues which should be solved through ecosystem-based Integrated Water Resource Management approaches. The manuscript briefly reviews why the issue of shifting to IWRM is a priority for Georgia, what actions are needed to be implemented, and what are the sequences of these actions.
\end{abstract}

Keywords: Water, Resources, Management, Floods

\section{Introduction}

Water resources management setup and practices in Georgia are relied on administrative approaches. Gradual introduction and implementation of the river basin based Integrated Water Resources Management (IWRM) will require corresponding legal and institutional adjustment as well as significant capacity building. The IWRM model for Georgia is intended to address prioritized concerns regarding water resource management, based on extensive consultations with stakeholders from a wide range of agencies and institutions related to water resources management.

Managing water efficiently, balancing conflicting uses of water resources, eliminating the results of catastrophic floods causing loss of human lives and damages to infrastructure and settlements and ensuring environmental stability of the river basins are critical issues which should be solved through ecosystem-based Integrated Water Resource Management approaches.

The manuscript briefly reviews why the issue of shifting to
IWRM is a priority and what actions are needed to be implemented and what are the sequences of these actions.

\section{Prepositions for Improved Water Resources Management in Georgia}

\subsection{Freshwater Resources in Georgia}

\subsubsection{Freshwater Supply}

Georgia has an abundance of fresh water resources - rivers, lakes, reservoirs, glaciers and springs. There are over 26,000 rivers with total channel length of some $60,000 \mathrm{~km}, 99.5 \%$ of which are rivers with a length less than $25 \mathrm{~km}$. Due to the Georgia's mountainous nature, there are very few rivers with a long channel length or large basin size - only 273 rivers are more than $25 \mathrm{~km}$ long.

Rivers in Georgia belong to two hydrological basins: the Black Sea Basin in the west and the Caspian Sea Basin in the east of the country. The Black Sea Basin is significantly richer in water resources compared to the Caspian Basin.

Rivers in Georgia have a good potential for all types of 
water uses, especially hydropower development and fisheries because of high channel slopes and high flow velocity. In terms of trans-boundary waters, Georgia is both an upstream and a downstream riparian, as water flows into Georgia from the Republic of Turkey and the Republic of Armenia, and flows out of Georgia - directly into the Black Sea, or indirectly into the Caspian Sea via Russian Federation or the Republic of Azerbaijan. Georgia is rich in ground water resources. The total volume of fresh ground water is estimated to be about 24 million cubic meters. Georgia also has more than 800 fresh water lakes.

Information on groundwater resources in Georgia is sparse, due to very limited hydro-geological monitoring data. Groundwater monitoring in Georgia stopped in the early 1990s, therefore estimates on groundwater reserves largely date back to the 1970-1980s. It is assumed that only about one third of the "known" groundwater resources have been surveyed in detail, and that total groundwater resources are estimated to be $18 \mathrm{BCM}$ with $67 \%$ in Western Georgia and $33 \%$ in Eastern Georgia [1].

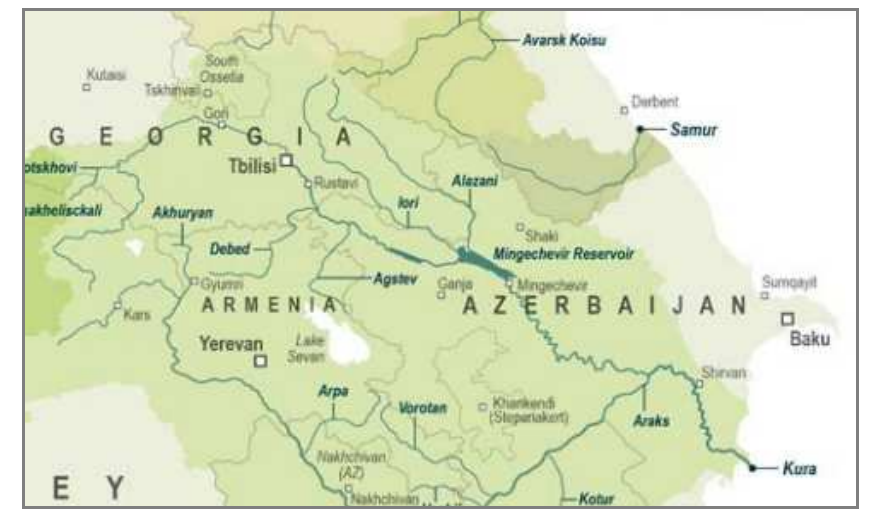

Figure 1. Georgia's trans-boundary surface waters

The mean annual precipitation value within Georgia is $1,338 \mathrm{~mm}$, and the mean annual precipitation volume is 93.3 $\mathrm{km} 3$. The mean annual total flow of rivers in Georgia is about $61.45 \mathrm{~km} 3$, generated in upstream the Republic of Turkey and the Republic of Armenia $(8.68 \mathrm{~km} 3)$ as well as within the country $(52.77 \mathrm{~km} 3)$ (table 1$)$.

Table 1. National Water Balance in Georgia, km3

\begin{tabular}{lllllll}
\hline \multirow{2}{*}{ Territory } & Local Flow & Transit Flow & Total Water Resources & Outflow & & \\
\cline { 6 - 7 } & & & & Into the Black Sea & Into the neighboring countries & Total \\
\hline West Georgia & 41.52 & 6.48 & 48.0 & 48.0 & & 48.0 \\
East Georgia & 11.25 & 2.20 & 13.45 & & 13.45 & 13.45 \\
Total & 52.77 & 8.68 & 61.45 & 48.0 & 13.45 & 61.45 \\
\hline
\end{tabular}

\subsubsection{Water Abstraction \& Consumption}

While overall Georgia is rich in water resources, accounting for that wealth is critical as multiple uses expand and overall demand increases. In addition, water is redistributed unevenly throughout the country. While the Western Georgia is abundant in water, the Eastern regions frequently suffer from water shortages.

- Municipal water supply

- Industry

- |rrigation

Fisheries

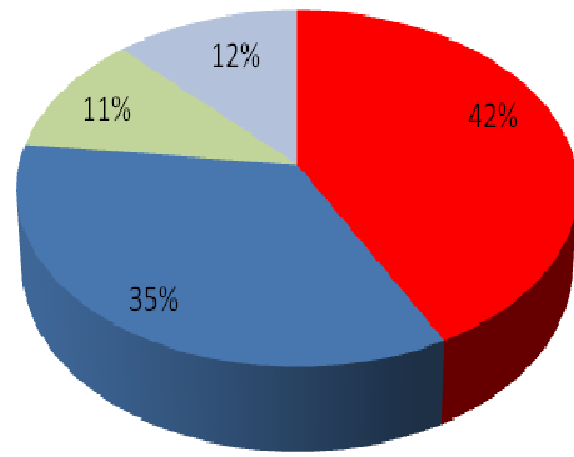

Figure 2. Water consumption by sectors in Georgia, excluding hydropower generation

Total water abstraction in Georgia in 2011 reached 22,767.4 $\mathrm{MCM}$, of which 381.21 MCM from groundwater sources, or
$1.67 \%$. Direct water consumption in the country, excluding hydropower generation totaled 1044.72 MCM, divided over the sectors of irrigation - $114.91 \mathrm{MCM}(11 \%)$, fisheries 126.04 MCM (12\%), industry - $357.92 \mathrm{MCM}$ (35\%), from which $291.95 \mathrm{MCM}$ falls on thermal power generation, and municipal \& drinking purposes - 439.15 MCM (42\%), while an additional volume of 20557.9 MCM was non-consumptively used by the hydropower sector [1].

\subsection{Changes in River Flows}

\subsubsection{Inter-Annual Variation}

Rivers in Georgia show significant inter-annual and seasonal variations in river flow, typically depending on variations in climatic conditions from year to year and season to season. Additionally, the expansion of human activities since the mid-20th century have impacted also on water use and river discharge in Georgia.

\subsubsection{Seasonal Variation}

The total amount of water being seasonally discharged through the country's rivers depends on the amount of snow in winter and rain in other seasons. Typically, the largest portion of the total annual discharge volume passes the rivers in spring, during the snow melting months of March through June/July. With envisioned climate change, typically an increase in the seasonal variation of river flow is expected, related to an increase/decrease of overall precipitation or an increase in the frequency and intensity of large storms, which may be 
associated with specific seasons.

\subsubsection{Climate Change}

There are two main climatic zones in Georgia, roughly separating the eastern and western parts of the country along the Likhi Ridge. The Black Sea coastal zone and much of Western Georgia are located within the humid subtropical zone with mild winters, hot summers and abundant precipitation. The prevalent climate in Eastern Georgia is drier, ranging from arid sub-tropical in the lowlands to alpine in the mountainous regions. Within these main zones climate conditions still are very diverse, largely conditioned by the heterogeneous topography. The Greater Caucasus Mountain Range plays an important role in moderating Georgia's climate, protecting the country against the penetration of colder air masses from the north. The Lesser Caucasus Mountains partially protect the country from the influence of dry and hot air masses from the south.

According to the climate forecast models climate change is expected to have significant impacts on the water resources of Georgia in terms of increased temperatures, reduced rainfall and reduced river flow in the coming few decades. In addition, climate change is expected to cause more intense and frequent extreme weather events including flooding/flashfloods, heat waves and droughts. To respond to these challenges, it is recommended to develop flood risk maps and flood hazard maps and develop flood management plans on their basis as it is outlined in the EU Directive on Assessment and Management of Flood Risks. It is also essential to develop early warning systems and conduct sufficient public awareness-raising to increase public's preparedness for emergency situations.

A complex mountainous topography makes the country more prone to the hydro-geomorphological processes and climatic hazards. As such, Georgia is vulnerable to natural hazards including floods, flash floods, earthquakes, droughts, landslides, avalanches, and mud flows. Catastrophic events that have an annual probability of occurrence of 0.5 percent threaten an economic loss for Georgia that exceeds 20 percent of the country's GDP. Floods, including flash floods are the catastrophic events of such category of high probability $[2,3]$.

\subsection{Extrime Events}

From extreme climate related events floods and flash floods are frequently observed in Georgia. The 1987 flood on the Lower Rioni River caused inundation of a vast territory including human settlements for a long period of time, resulting in some casualties and huge damage to the local agricultural sector. In 1997, the flood events in the Tbilisi-Gori-Kvemo Kartli region killed 7 people, affected 500 others and incurred a reported economic loss of \$US 29.5 million. In June 2005, the flood in the Mtskheta-Tianeti region killed 2 people, affected 51 others and caused an economic loss of \$US 2 million. On 13 May 2012, the flood in Tbilisi killed 5 people and caused several million dollars in damages. In the period of 1995-2010 in total 164 flood events occurred throughout Georgia with the total impact of \$US 272.3 million [4].
While Georgia emerges as the most vulnerable in the broader region of Eastern Europe and Central Asia for the period of 1980-2000, measured by the mortality rate among those exposed to floods, since 2004 considerable improvements in the institutional landscape to manage flood risks and support timely recovery have occurred. However, much remains to be done and levels of vulnerability and exposure are still high [5].

Some traditional flood risk management measures have a negative impact on the quality and quantity of waters. Examples can be building of dams or dikes which change the river flow by reducing water for related ecosystems in the area of which accentuate problems in dry seasons by alerting the natural flow of the river and may even increase flooding downstream [6].

Increased population pressure and enhanced economic activities in floodplains, such as the construction of buildings and infrastructure, further increase the risk of flooding. Floodplains provide excellent, technically easy livelihood opportunities in many cases. In developing countries with primarily agricultural economies, food security is synonymous with livelihood security. Floodplains contribute substantially to the food production that provides nutrition for the people of these countries [7].

The urgent need for increasing flood security is also illustrated by the fact that the majority of the members of Georgian society that are vulnerable to floods are women, children and the poor. Internally Displaced People (IDPs), a large portion of who inhabit western regions of the country are among the most socially disadvantaged groups in the country.

\subsection{Improvement of Water Resources Management}

\subsubsection{EU - Georgia Association Agreement}

The European Union (EU) - Georgia relations started in 1992 after Georgia regained its sovereignty in the wake of the break-up of the Soviet Union following the recognition of Georgia's independence by the European Union. Relationships with EU upgraded after Georgia became a part of the Eastern Partnership initiative since its launch in 2009. Under this initiative, closer political association and economic integration with the EU is being promoted. The EU and Georgia completed the negotiation of the Association Agreement between the European Union and the European Atomic Energy Community and their Member States, of the one part, and Georgia, of the other part (AA), including the Deep and Comprehensive Free Trade Area (DCFTA) element, in July 2013 and initialed the Association Agreement at the Eastern Partnership Vilnius Summit in November 2013. Ultimately, both sides signed the Agreement on $27^{\text {th }}$ June 2014.

The Association Agreement creates new legal framework for co-operation with the EU. It is a comprehensive and politically stronger document with the potential to lead co-operation between Georgia and the European Union towards qualitatively new and higher levels in many important sectors. Besides political and economic association the AA covers a broad range of topics, including regulatory 
approximation in the field of environment, climate change and natural resources protection to some extent.

The environmental parts of the Association Agreement envisage a progressive opportunity for gradual harmonization with EU environmental rules and standards with the objective to protect environment and ecosystem and encourage effective environmental governance including water resources management. The Association Agreement includes specific provisions of six EU Directives concerning water quality and resource management, including marine environmental policy [8].

\subsubsection{Decentralizing Water Management to a Basin Level}

In order to comply with the requirements of the Association Agreement Georgia faces a number of structural environmental challenges such as improving environmental legislation, increasing awareness of stakeholders, improving monitoring, inspection and enforcement systems, and strengthening the knowledge for adequate policy-making.

Although some progress has been made in Georgia in water sector development, there are still significant difficulties in terms of legal and institutional frameworks and law enforcement. The Government of Georgia is currently working towards harmonization of its institutional settings and legislation with those of the European Union, including water resources management in line with the requirements of the United Nations Economic Comission for Europe (UNECE) Convention on the Protection and Use of Transboundary Watercourses and International Lakes, which also includes improvement of water resources management.

The purpose of adopting IWRM and its principles is to improve the way water resources are managed in a situation where improved management is necessary, conditioned by increasing pressures on the resources from human activities and climate change. According to the Global Water Partnership, "Integrated Water Resources Management is a process which promotes the coordinated development and management of water, land and related resources, in order to maximize the resultant economic and social welfare in an equitable manner without compromising the sustainability of vital ecosystems"[9].

Currently, water resources management is strongly centralized in Georgia with the Ministry of Environment and Natural Resources Protection being a key entity and the government is striving to shift to IWRM according to the guidelines of the UNECE Convention on the Protection and Use of Transboundary Watercourses and International Lakes and the obligations under the Association Agreement.

Main concerns relate to the inefficient use of water and to its environmental and socio-economic consequences: low river flows, water shortages, salinisation of freshwater bodies in coastal areas, human health problems, loss of wetlands, desertification and reduced food production. The main challenge of modern management is to ensure a sustainable management of water resources, avoiding overexploitation and degradation, so as to maintain an adequate supply of freshwater of suitable quality for human use and to support aquatic and other ecosystems. This implies reducing losses, using more efficient technologies and increase recycling, and applying an integrated approach to the management of freshwater resources by river basin. It further requires applying the user pays principle to all types of uses [10].

\subsubsection{Transition Process}

The transition period from one management system to another in the proper resources management is measured in multiples of years, and requires many legal and institutional changes. As the first step it is necessary to create a platform for establishing water management at a basin level. River basin is a unit for implementing IWRM and river basin authorities should be responsible for the development and implementation of river basin management plans. The Ministry of Environment and Natural Resources Protection of Georgia can have a lead role in guiding and supporting river basin authorities through this process, especially at the initial stages. It is also necessary to create a river basin councils - a platform for involvement and participation of all water user stakeholders in the river basin management.

Climate change also expected to aggravate extreme natural events such as floods. To respond to these challenges, it is recommended to develop flood risk maps and flood hazard maps and develop flood management plans on their basis as it is outlined in the EU Directive on Assessment and Management of Flood Risks. It is also essential to develop early warning systems and conduct sufficient public awareness-raising in terms of preparedness for emergency situations.

In the first phase will be initiated data collection and other activities for preparation to development of flood risk maps and flood hazard maps; climate parameters will be collected and analyzed; early warning systems will be developed; and flood risk maps and flood hazard maps will be developed based on the previous preparation activities. In the second phase modeling (application of selected models) for making a prognosis on impacts of climate change on water resources will be done and climate change adaptation plans will be developed based on data obtained in the first phase and on the basis of the forecasts made based on the models. In addition, flood risk management plans will be developed based on the flood risk maps and flood hazard maps. Through the both phases awareness raising activities will be implemented to increase public's awareness on climate change adaptation as well as overall preparedness for emergency situations.

\subsubsection{Development of Flood Risk Maps and Flood Hazard Maps}

Development of flood risk maps and flood hazard maps requires the undertaking of preliminary flood risk assessment in each river basin management unit. This involves gathering of information on the floods that have occurred in the past, the likelihood of future floods and estimated consequences of these floods. Based on this information river basins are categorized according to flood risks. The next step will be development of flood risk maps and flood hazard maps. 
Flood risk maps and flood hazard maps identify all areas at risk of flooding and indicate the probability of flooding (high, medium or low) for each of those areas. Flood hazard maps also show the extent of possible flooding, while flood risk maps indicate the potential damages that could occur under each flood scenario [11].

\subsubsection{Development of Flood Risk Management Plans}

Based on flood risk maps and flood hazard maps, flood risk management plans should be developed. Floor risk management plans will include measure focusing, reducing the probability of flooding and the potential consequences of flooding, covering all aspects for floods management: prevention, protection and preparedness.

\subsubsection{Obtain Climate Parameters for the Climate Change Forecast Model}

The use of most updated climate change models will enable increased accuracy in predictions. Predicting climate change impacts on water resources and water availability will be critical for long-term planning and sustainable development. The main activities for this issue are:

- Digitalize historical hydro-meteorological data

- Select climate change model(s);

- Select model(s) for climate change impact prognosis;

- Obtain climate parameters for the climate change forecast model;

- Apply the climate change impact forecast model(s) to different scenarios;

- Assess the results of modeling for different climate change scenarios in terms of impacts on water resources.

\subsubsection{Increase the Public Awareness and Overall Preparedness for Emergency Situations}

Extensive public awareness activities will be needed in order to increase overall awareness of the public on climate change and adaptation as well as on preparedness for emergency situations. This will help to successful implementation of the climate change adaptation measures and also will ensure timely and effective implementation of emergency measures when needed.

\section{Results}

River basin management should be implemented based on river basin management plans. River basin management plans are developed by river basin authorities according to the requirements of the EU Water Framework Directive (WFD). Development of river basin management plans requires extensive preparation activities including studying physical, chemical and hydro-morphological characteristics of river basins, identifying impacts, conducting economic analysis of water use, developing systems for water quality status assessment, developing program of measures etc. Detailed guideline for the development of river basin management plans is provided by the EU WFD.

As for water policy and law making, Georgia is required to identify river basin districts and analyze their characteristics, establish programmes for monitoring water quality and prepare river basin management plans in consultation with public:

- "Identification of River basin districts and establishment of administrative arrangements for international rivers, lakes and coastal waters";

- Preparation of river basin management plans, consultations with the public \& publication of these plans" [12].

For assessment and management of flood risks, Georgia is required to undertake flood assessments, prepare flood hazard and risk maps and establish flood risk management plans.

The Directive on the Assessment and Management of Flood Risks complements the Water Framework Directive. Its objectives are to reduce the adverse consequences for human health, the environment, cultural heritage and economic activity associated with all types of floods and assessment and management of flood risks and it requires that prevention and management measures are organized on a basin level.

The Directive regulates: carrying out an assessment of potential risks, undertaking preliminary flood assessment; having a basis for priority setting and decision-makings regarding flood risk management; maps are supposed to show the potential adverse consequences associated with different flood scenarios, preparation of flood hazards maps and flood risks maps; implementation of measures for management of flood risks including costs and benefits; establishment of flood risk management plans:

- "Undertaking preliminary flood assessment";

- "Preparation of floods Hazards map and flood risk maps";

- "Establishment of Flood Risk management Plans" [13].

An Integrated Flood Management (IFM) approach is also an essential component of Integrated Water Resources Management and such an approach can help to balance flood risk management and development needs. Integrated Flood Management is a process, promoting an integrated - rather than fragmented - approach to flood management. It integrates land and water resources development in a river basin, within the context of IWRM, and aims at maximizing the net benefits from the use of floodplains and minimizing loss of life from flooding [6].

At different times floods caused inundation of vast territories, including human settlements resulting in huge damage to the local economy and agriculture and causing even casualties. It is predicted, that climate change will cause more intense and frequent extreme weather conditions, including flooding. Preparation for these events will enable flood risks to be assessed and flood damages to be minimized/prevented. EU Directive on Assessment and Management of Flood Risks provides a common framework and detailed guidelines for assessing and reducing the risk that floods pose to human health, economy and the environment. The EU Floods Directive is closely linked with the EU Water Framework Directive, so as it requires that prevention and management measures are organized on a 
basin level.

\section{Conclusions}

As an integral part of Integrated Water Resources Management (IWRM), Integrated Flood Management (IFM) faces similar challenges. The effective implementation of both IWRM and IFM requires an enabling environment in terms of policy and legislation; clear institutional roles and functions; and management instruments for effective regulation, monitoring and enforcement.

\section{References}

[1] IWRM plan for Georgia, GEF/UNDP project "Reducing transboundary degradation in the Kura-Aras river baisin", 2014 unpublished.

[2] Adapting to climate change in Europe and Central Asia, World Bank, 2009, p.89.

[3] D. Kereselidze, L. Matchavariani, V. Trapaidze, L. Lagidze, G. Dokhnadze, N. Tkhilava, N. Gokhelashvili. Evaluation and Management of the Risk of Flooding River Bank. Engineering Geology for Society and Territory. Vol.3: River Basin, Reservoir Sedimentation and Water Recourses. SPRINGER International Publishing Switzerland, 2015, 463-469.

[4] EM-DAT, The International Disaster Database, The Centre for Research on the Epidemiology of Disasters - CRED http://www.emdat.be/result-country-profile.
[5] Developing climate resilient flood and flash flood management practices to protect vulnerable communities of Georgia, Adaptation Fund/UNDP project, 2012, unpublished.

[6] Towords better environmental options for flood risk management, European Comission, unpublished.

[7] Integrated flood management, concept paper, world Meteorological Organization, WMO-No. 1047,

[8] Association Agreement between the European Union and the European Atomic Energy Community and their Member States, of the one part, and Georgia, of the other part.

[9] Integrated water resources management, Global Water Partnership Technical Advisory Committee, 2000, Stockholm. Technical Background Paper No. 4.

[10] Key environmental Indicators, OECD, 2008, 20-23.

[11] J. Schanze, Flood risk management - a basic framework hazards, vulnerability and mitigation measures. Springer, 2006, pp. 1-20.

[12] Directive 2000/60/EC of the European Parliament and of the Council, WFD, Articles 3 (1) - 3(7), 13, 14.

[13] Directive 2007/60/EC of the European Parliament and of the Council on the assessment and management of flood risks, Articles 4,5, 6, 7 . 